\title{
MEDICAL NEWS
}

\section{Changes at Department of Health and \\ Social Security}

The Secretary of State for Social Services has approved the following appointments:

Miss MILDREd RIDDELSDELl, at present a deputy secretary in the Department of Health and Social Security, is to be second permanent secretary with responsibility in the field of social security, in succession to Sir AlaN MarRe; Mr. LANCELOT ERRINGTON, at present an under secretary in the Department, is to be a deputy secretary with particular responsibility for national insurance, industrial injuries, and war pensions; Mr. N. JORDANMoss, at present an under secretary in the Treasury, will fill a new post as a deputy secretary with responsibility for the administration of the personal social services.

\section{Social Work Council}

The Government announced last week the setting up of a Central Council for Education and Training in Social Work. It will be concerned with training in social work for local-authority health and welfare services, for the children's service, the hospital service (both general and psychiatric), for the probation and aftercare service, and similar services provided by voluntary organisations. Established under the Health Visiting and Social Work (Training) Act 1962, the new council replaces two existing bodies-the Council for Training in Social Work and the Central Training Council in Child Care. The new council will have a chairman appointed by Ministers, and 51 other members, seven of whom will be appointed by Ministers and one by the Governor of Northern Ireland. One will be appointed by the B.M.A.

\section{Cholera Control}

Principles and Practice of Cholera Control, a new modern 140-page handbook which outlines practical measures against the disease, was issued by the World Health Organization at the beginning of December with a warning that the current pandemic of cholera may spread to new areas. According to this publication, which gives the different schedules of treatment for adults and children, effective treatment of cholera can reduce fatality to less than one per cent.

\section{Guild of Medical Ringers}

A membership approaching 100 was reported at the guild's recent annual meeting. This includes nurses and members of professions allied to medicine as well as doctors. Mr. D. J. NEAL SMITH was elected president, Mr. D. G. H. Hollis master, and Dr. D. L. Gullick secretary. After the annual meeting some members of the guild took part in a unique occasion-a complimentary quarter peal on the bells of Lambeth parish church to mark the recent retirment from the staff of Middlesex Hospital of Mr. W. R. Winterton, a past-president of the guild.

\section{B.M.A. Christmas Cards}

Unexpected difficulties, outside the Association's control, have occurred in the printing of B.M.A. Christmas cards. As a result it may not be possible for all orders to be met. This is deeply regretted.

\section{Mr. Tom Palmer}

At the age of nearly $93 \mathrm{Mr}$. Tom Palmer retires from the B.M.f. at the end of this year. He joined the staff as head reader on 23 August 1926, became head copypreparer in 1937, and officially retired in

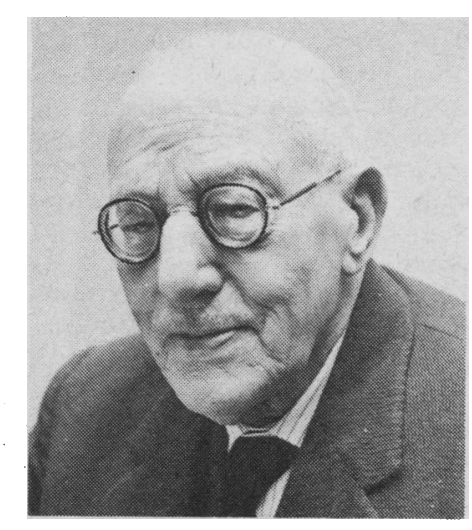

Barratts Photo Press, Ltd.

1942. Working normal office hours ever since, he now goes into a more restful retirement with the cordial good wishes of all his colleagues.

\section{Coming Events}

"Man, Medicine and the Mass-media."Symposium, 10 January, Greygarth University Hall, Manchester. Registration fee $£_{1}$. Applications to the course organizer, Dr. L. J. Dolan, The Thorns, Prestwich Park Road South, Prestwich, Manchester.

\section{Universities and Colleges}

\section{LONDON}

The title of reader in medicine has been conferred on Dr. I. A. D. Bouchier in respect of his post at the Royal Free Hospital School of Medicine.

The title of reader in histopathology has been conferred on Dr. A. G. Stansfeld in respect of his post at St. Bartholomew's Hospital Medical College.

\section{ROYAL COLLEGE OF SURGEONS OF ENGLAND}

At a meeting of the council held on 10 December, with Sir Thomas Holmes Sellors, president, in the chair,- the deaths of Mr. Eric L. Farquharson, of Edinburgh (member of council and past member of the court of examiners), and of Professor Martin A. Rushton (past dean of Faculty of Dental Surgery) were reported with deep regret.

Mr. P. S. Henman (past chairman, Transport Development Group Ltd.) and Mr. E. J. Partridge (president, Confederation of British Industry) were elected members of the court of patrons.

Sir Henry Osmond-Clarke was appointed the Bradshaw lecturer for 1971.

Professor J. G. Robson was invited to be the Joseph Clover lecturer for 1972.

Dr. Lester Cahn was appointed Menzies Campbell lecturer for 1968-71.

A diploma of membership was granted to R. L. Tambyraja.

\section{ROYAL COLLEGE OF SURGEONS OF} EDINBURGH

At a meeting of the College held on 11 December, with Professor D. M. Douglas, president, in the chair, the following were admitted as Fellows:

Y. H. Abdullah, N. V. Achan, T. R. Achuthan, O. O Adekunle, M. A. F. Adham-Sikhtian, M. Ahmad, $R$ Ahmad, B. Akinsanya, A. Akuma, S. Al-Atrakchi, S. I Al-Khaidhaire, M. H. Amer, A. A. D. K. Ampoma. H. C. Anyanwu, S. G. Badrudduja, R. N. Baird, R Choudhury T. MCC. Col, A. T C Cargill, Bimalend Das $R$ J Deai, G. Coltart, T. C. Cooney, Lala J. $R$ M. Y. Dhar, N. A. Dinaneni A. H. El-Masri, H, R A A El Rahman, M. F. Fad lal Y. H. El-Masri, H. R. A. Fernandes, R. K. Gandhi, A. W. Grant, Nazir N. Guirguis, M. Hardingham, D. G. Hardy, D Nazir Nay, J. H. Hay, C. E. Hoare, D. R. Kadambi, B. A. Kamdar, $M$. Lakshminarayana, Ling K. Leung, O. R. LongJohn, R. F. Mather, K. S. Mathur, R. MacG. Milne Firoz D. Mistry, S. K. Mitra, M. C. Modi, H. S. R. Mohan Rao, S. Mukheriee, R. G. Morgan, D. H. Nave, S. A. Ojo, K. Owusu, A. J. F. Penco, C. K. Rathore S. C. Ray, R. W. Rushman, N. K. Saad, K. N. Seal, R. Sekel, P. S. Selvachandran, D. K. Sengupta, D. D Shah, Anand B. Sinha, M. Sivanathan, F. D. Snyckers . S. Rajah, A. C. Southall, J. N. L. Srivastava, J. Tembe, M. G. Tershakowec, E. J. Theron, D. J Thomas, W. M. C.Thomas, B. H. Underwood, M. V Venkatachala, V. K. Varma, P. A. Walker, J. W
Ware, G. S. Watson, R. G. Wilson, M. A. Zaman.

Ware, G. S. Watson, R. G. Wilson, M. A. Zaman

\section{ROYAL COLLEGE OF PHYSICIANS} AND SURGEONS OF GLASGOW

At a meeting of the College held on 7 December, with the president, Professor E. M. McGirr, in the chair, the following were elected as Fellows qua Physician:

G. J. Addis, A. Animashaun, R. A. Blair, J. Buchanan, K. D. Crochanan, D. A. Cannon, T. J. L. C. Dali, W. A. Dewar, M. G. Dunnigan, J. V. G. A. Durnin, G. J. Ebrahim, M. Fletcher, R. B Goudie, W. C. Love, J. C. Maclaurin, I. B. Munro W. R. Murdoch, R. Murray, Freda M. Paul, Wai-on Provan, I. W. Pinkerton, J. R. R. Preston, G. C Provan, J. H. Renwick, M. J. Riddell, J. Ronald, Shulman, E. A. Smith, W. T. Strauss, G. Watkinson.

\section{Corrections}

Clofibrate and the Fibrinolytic System

In a letter by Dr. R. C. Cotton (12 December. p. 83) the word "thrombolytic" was wrongly printed for "thrombotic" in line 14 of its second paragraph. The sentence should have read: "We have noted, however, that if an infective or thrombotic episode occurs in patients receiving these preparations then the temporary rise in fibrinogen and depression of fibrinolysis which results from these conditions still occurs."

\section{Follow-up of Intensive Therapy}

In the article on "Subjective Follow-up of Patients from Surgical Intensive Therapy Ward" by P. B. Hewitt (12 December, p. 669) the heading to Table III should have read: "Accuracy of Estimates of Duration of Ventilation by Patients on Entonox".

\section{Notice to Authors}

When original articles and letters for publication are not submitted exclusively to the British Medical fournal this must be stated.

Correspondence on editorial business should be addressed to the Editor, British Medical foumal, B.M.A. House, Tavistock Square, London WC1H 9JR. Telephone: 01-387 4499. Telegrams: Aitiology, London W.C.1.

Authors wanting reprints of their articles should notify the Publishing Manager, B.M.A. House, Tavistock Square, WC1H 9JR, on receipt of proofs. 